\title{
TUBERCULOUS ISCHIO-RECTAL ABSCESS AND PRIMARY PULMONARY TUBERCULOUS COMPLEX IN A FIVE-MONTHS-OLD INFANT
}

BY

\author{
B. GANS \\ From the Miller Hospital, Greenwich
}

(Received for Publication March 20, 1950)

The occurrence of a tuberculous ischio-rectal abscess complicating a primary pulmonary focus in a five-months-old infant is considered sufficiently unusual to warrant the following description.

\section{Case Report}

The baby weighed $5 \mathrm{lb} .9 \mathrm{oz}$. at birth. He was breast fed for two months, and then changed to a dried milk mixture. His weight gain was moderately good, he was lively, his appetite was satisfactory, and he had not been constipated. At the age of 1 month he developed a cough which had persisted, and at the age of 5 months he developed a 'boil' on his left anal margin which would not heal.

The child's mother and two siblings were well, but his father, who lived at home, had open pulmonary tuberculosis.

When first seen, at the age of 29 weeks, the child weighed $14 \mathrm{lb} .8 \mathrm{oz}$., was well hydrated, and did not appear ill. Apart from some pallor the only abnormality found was a punched-out, oval ulcer, measuring $\frac{3}{4}$ in. by $\frac{1}{2}$ in. with undermined, dusky blue edges, at the left anal margin (Fig. 1). The ulcer base was filled with soft, ragged, pale granulations. Exploration with a probe revealed a $\frac{3}{4}$ in. long track running medially to a cavity adjacent to, but not communicating with, the rectum. The rectal mucosa was normal on proctoscopy.

The child had a low grade pyrexia (up to $100^{\circ}$ F.). His Mantoux reaction, 1:10,000, was positive. The sedimentation rate was $37 \mathrm{~mm}$. in the first hour. A blood count gave $\mathrm{Hb} .63 \%$; red cells $4 \cdot 1$ million; white cells 15,000 per c.mm (P. $44 \%$, L. 52\%, M. 4\%). Repeated examinations of stomach washings and stools for acid-fast bacilli were negative. A swab from the ulcer yielded a coagulase positive Staph. aureus, but no tubercle bacilli. No culture or guinea-pig inoculation was carried out. A punch biopsy (Fig. 2) from the ulcer edge showed numerous giant cell systems, and in a Ziehl-Neelsen preparation moderate numbers of

Fig. 1.-Tuberculous ischio-rectal abscess in a five-months-old baby. acid-fast bacilli were seen within the giant cells in all the sections examined. A chest radiograph showed a right middle lobe collapse (Fig. 3), which, at bronchoscopy, was found to be due to compression of the middle lobe orifice from without. The carina was flattened, and no endobronchial lesion was seen.

Treatment consisted of the daily intramuscular

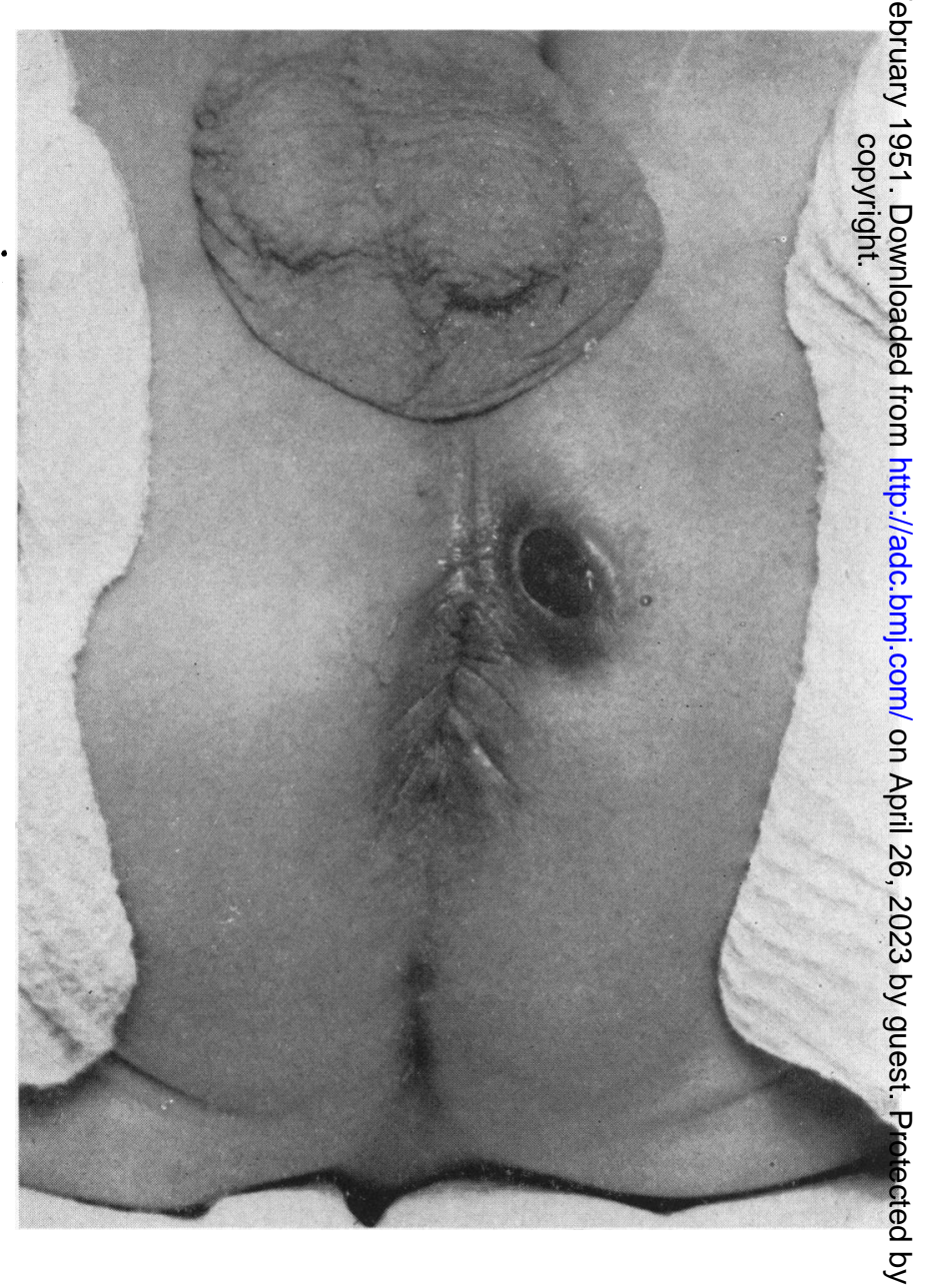




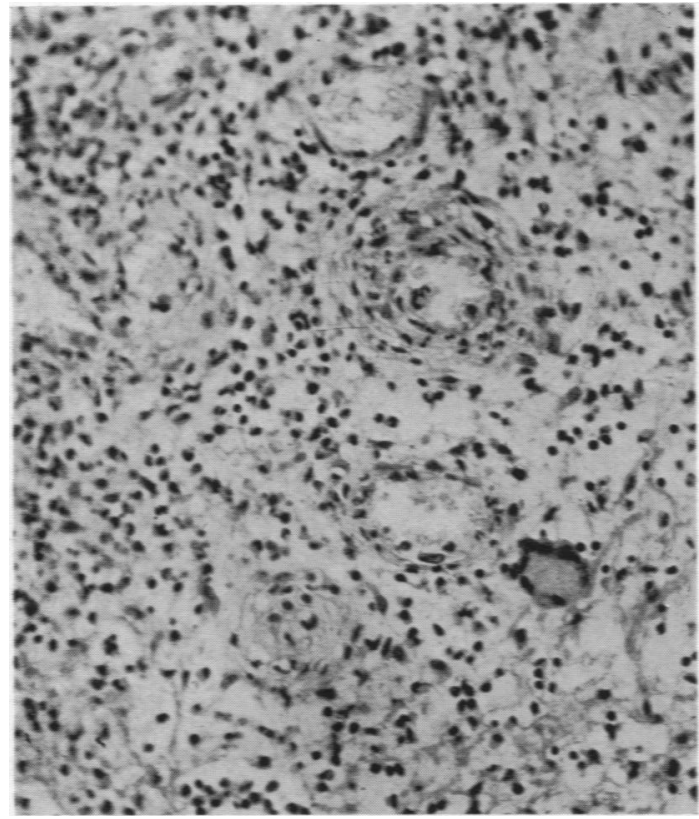

Fig. 2.-Photomicrograph of punch biopsy showing a giant cell. Haematoxylin and eosin. $\times 220$.

injection of $0.36 \mathrm{~g}$. streptomycin for eight weeks; the local application of a paste containing P.A.S. 20 g., sulphathiazole $5 \mathrm{~g}$., Haldane's emulsifying base ad $100 \mathrm{~g}$; and an iron mixture by mouth. As no ischiorectal fistula was present, it was decided that surgical intervention was unnecessary. On this treatment the ulcer healed in a month, the pyrexia subsided, the anaemia disappeared, and the child gained weight. The middle lobe collapse has now persisted for seven months.

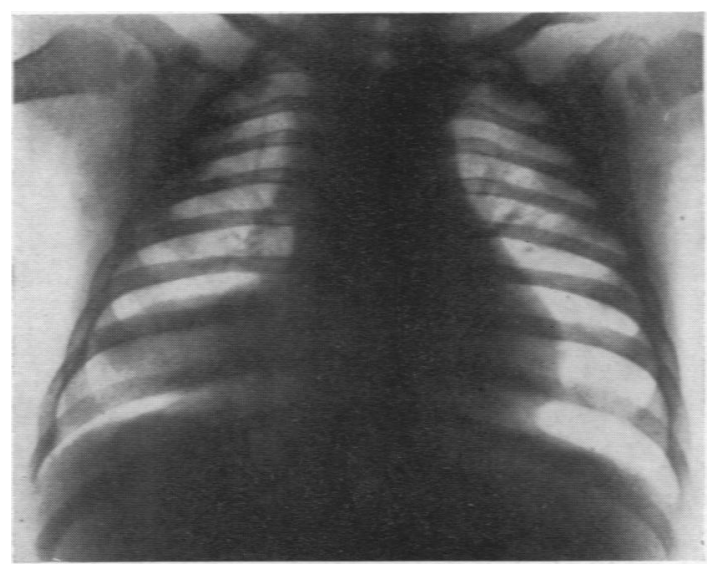

FIG. 3.-Radiograph showing right middle lobe collapse.

\section{Discussion}

Reports on the incidence of tuberculous ischiorectal ulceration in cases of pulmonary tuberculosis vary widely. Granet (1940) found that perianal infections were ten times more common in tuberculous subjects than in the non-tuberculous, but considered that they arose primarily as non-specific infections with secondary tuberculosis superadded. This view is shared by Zadikoff (1947) who found that $28 \cdot 9^{\circ}$ \% of 1,000 cases of pulmonary tuberculosis had rectal lesions. Aronsson (1948), in a study of 356 cases of anal ulceration in tuberculous pat ents found the incidence to be between 2.5 and $5^{\circ}$. Few authors mention the age of their patients, but Goorwitch (1942) could find only one 15-year-old patient recorded in the literature, and added a 13-year-old patient of his own. In all these the rectal ulceration was a complication of open pulmonary tuberculosis, and no reference could be found to patients with a primary pulmonary tuberculous focus, that is, a closed' focus, associated with a tuberculous ischio-rectal lesion.

All authors draw attention to the difficulty of proving the tuberculous aetiology of perianal infection in tuberculous patients. Martin, Lansford, and Sweany (1940) point out that the mere presence of acid-fast bacilli in perianal lesions does not prove their tuberculous aetiology, as patients with pulmonary tuberculosis swallow their sputum. According to Martin and Sweany (1940) a $33^{\circ}$. error arises if reliance is placed solely on culture or inoculation experiments. Though foreign body giant cells do occur in simple pyogenic ischio-rectal lesions (Henschen, 1924), most authors agree that the demonstration by histopathological methods of acid-fast bacilli in association with giant cell systems is adequate proof of the tuberculous nature of the lesion (Jackman and Buie, 1946: Aronsson, 1948).

\section{Summary}

A case of a primary pulmonary tuberculous complex, complicated by an ischio-rectal abscess. is reported in a five-months-old child. The tuberculous nature of the perianal lesion was proved by histopathological methods.

\section{REFERENCES}

Aronsson. H. (1948). Acta chir. scand.. 96, Suppl. 135. Goorwitch, J. (1942). Amer. Rev. Tuberc.. 45, 410.

Granet, E. (1940). Ann. Surg., 112, 440.

Henschen, F. (1924). Acta path. microbiol. scand., 1, 56,351 .

Jackman, R. J., and Buie, L. A. (1946). J. Amer. med. Ass., 130, 630.

Martin, C. L., Lansford, W. I., and Sweany, H. C. (1940). Amer. J. digest. Dis., 7, 36.

and Sweaney, H. C. (1940). Surg. Ginec. Obstet., 71, 295.

Zadikoff, I. J. (1947). C Clin. Proc., 6, 223. 